\title{
UPAYA MENINGKATKAN MINAT BELAJAR IPS PADA SISWA DENGAN MEDIA PEMBELAJARAN POWER POINT
}

\author{
Dewi Oktapia ${ }^{1}$, Yeni Asmara', Risa Marta Yati ${ }^{3}$ \\ STKIP PGRI Lubuklinggau ${ }^{1,2,3}$ \\ yeni.stkip@gmail.com ${ }^{1}$
}

\begin{abstract}
ABSTRAK
Penelitian ini bertujuan untuk mengetahui pengaruh media pembelajaran powerpoint terhadap minat belajar siswa pada mata pelajaran IPS kelas VIII di SMP Negeri Sumber Harta. Metode penelitian yang digunakan adalah eksperimen murni. Penentuan sampel dilakukan dengan menggunakan teknik simple random sampling dari populasi seluruh siswa kelas VIII, dan 50 siswa terpilih menjadi sampel adalah kelas VIII A (kelas eksperimen) diberikan perlakuan pembelajaran dengan media pembelajaran powerpoint dan kelas VIII B (kelas kontrol) tidak diberi perlakuan. Teknik pengumpulan data dalam penelitian menggunakan metode angket yang telah diuji validitas dan uji reabilitas. Hasil penelitian menggunakan rumus persentase didapatkan hasil yaitu 23 siswa dikategorikan sangat berminat (SB) dengan persentase $92 \%$ dan 2 siswa di kategorikan berminat (B) dengan persentase $8 \%$, sedangkan siswa yang dikategorikan kurang berminat (KB) dan siswa yang tidak berminat (TB) sebanyak 0\% atau tidak ada. Simpulan, ada pengaruh yang signifikan media pembelajaran menggunakan powerpoint terhadap minat belajar siswa
\end{abstract}

Kata Kunci: Pengaruh, Powerpoint, Minat Belajar.

\begin{abstract}
This study aims to determine the effect of powerpoint learning media on student interest in social studies subjects VIII in Sumber Harta State Junior High School. The research method used is pure experimentation. Determination of the sample is done by using simple random sampling technique from the population of all students of class VIII, and 50 students selected as samples are class VIII A (experimental class) given learning treatment with powerpoint learning media and class VIII B (control class) is not treated. Data collection techniques in the study using a questionnaire that has been tested for validity and reliability testing. The results of the study using the percentage formula showed that 23 students were categorized as very interested $(S B)$ with a percentage of $92 \%$ and 2 students were categorized as interested $(B)$ with a percentage of $8 \%$, while students who were categorized as less interested $(K B)$ and students who were not interested (TB) ) as much as $0 \%$ or none. Conclusion, there is a significant influence of learning media using powerpoint on students' learning interest in social studies
\end{abstract}

Keywords: Influence, Powerpoint, Interest in Learning. 


\section{PENDAHULUAN}

Perkembangan Teknologi Informasi dan Komunikasi (TIK) telah banyak memberikan kontribusi terhadap terjadinya revolusi dalam berbagai bidang kehidupan manusia termasuk bidang pendidikan. Penggunaan media dalam pembelajaran mempunyai peran yang besar terhadap pencapaian tujuan pembelajaran. Tersedianya media sangat penting untuk merangsang kegiatan dan Minat belajar siswa.

Menurut peneliti media yang paling tepat untuk meningkatkan Minat belajar siswa yaitu media pembelajaran power point karena lebih mudah dipahami siswa. Penelitian oleh Dona Fitriyani yang meneliti tentang pengaruh media pembelajaran power point terhadap minat belajar sejarah siswa Kelas X di SMA Gajah Mada Bandar Lampung mendapatkan hasil bahwa penggunaan media pembelajaran power point dalam pembelajaran sejarah terhadap minat belajar siswa dapat dikatakan berpengaruh signifikan. Hal ini ditunjukan dengan hasil tes angket yang menunjukan adanya peningkatan persentase siswa yang berminat terhadap pelajaran setelah menggunakan media pembelajaran power point.

SMP Negeri Sumber Harta merupakan sekolah menengah pertama yang terletak di Kecamatan Sumber Harta Kabupaten Musirawas. SMP Negeri Sumber Harta sudah terakreditasi B dan siap bersaing dengan SMP lainnya di Kabupaten Musirawas. SMP Negeri Sumber Harta dipilih peneliti untuk dijadikan lokasi penelitian untuk mencari informasi tentang Pengaruh Media Pembelajaran Power Point Terhadap Minat Belajar Siswa pada Mata Pelajaran IPS Kelas VIII karena sekolah ini sudah memiliki infranstruktur penunjang seperti LCD, Laptop dan pada mata pelajaran IPS guru juga sudah menerapkan media pembelajaran power point ini namun hanya pada kelas VII sedangkan pada kelas VIII dan IX guru masih menggunakan metode konvensional.

Berdasarkan hasil observasi awal yang dilakukan peneliti kepada guru mata pelajaran IPS kelas VIII yaitu Ibu Herlina, S.Pd, pada tanggal 09 Mei 2018 di SMP NegeriSumber Harta, diketahui bahwa mata pelajaran IPS kelas VIII masih menggunakan kurikulum KTSP dan dalam proses pembelajarannya guru masih menggunakan metode konvensional yaitu ceramah dan diskusi, namun minat belajar siswa dirasa masih kurang baik. Hal ini dapat dilihat dari suasana kelas pada saat guru mengajar menggunakan metode konvensional cenderung tenang saat diskusi berlangsung dan siswa juga cenderung pasif, hanya beberapa siswa saja yang terlihat aktif.

Penggunaan metode diskusi yang diterapkan guru di SMP Negeri Sumber Harta pada mata pelajaran IPS di kelas VIII dirasa peneliti kurang tepat karenabelum mampu meningkatkan minat belajar siswa yang berdampak terhadap rendahnya hasil belajar siswa di SMP Negeri Sumber Harta. Hal ini dapat dilihat dari Kriteria Ketuntasan Minimal (KKM) mata pelajaran IPS pada kelas VIII adalah 73. Dari jumlah siswa kelas VIII di SMP Negeri Sumber Harta sebanyak 
128 orang, hanya $21(16,41 \%)$ orang yang mencapai KKM dan sisanya yaitu 107 $(83,59 \%)$ orang tidak mencapai KKM.

Menyadari akan hal tersebut, peneliti tertarik untuk mengadakan penelitian di SMP Negeri Sumber Harta. Penelitian ini dilaksanakan menggunakan media yang dapat meningkatkan minat belajar IPS pada siswa kelas VIII di SMP Negeri Sumber Harta. Media yang digunakan adalah media pembelajaran power point.Tujuannyauntuk mengetahui apakah ada dampak yang signifikan dari penggunaan media pembelajaran power point terhadap minat belajar siswa di SMP Negeri Sumber Harta.

Menurut Crow \& Crow dalam Djaali (2008) Minat adalah gaya gerak yang mendorong seseorang untuk menghadapi atau berurusan dengan orang, benda, kegiatan, yang dirangsang oleh kegiatan itu sendiri. Minat adalah kecenderungan yang tetap untuk memperhatikan dan mengenang beberapa kegiatan. Kegiatan yang diminati seseorang maka akan diperhatikan terus-menerus yang disertai dengan perasaan senang (Slameto, 2003). Minat belajar adalah suatu rasa lebih suka dan rasa keterikatan pada suatu hal atau aktivitas, tanpa ada yang menyeluruh. Minat terhadap sesuatu merupakan hasil belajar dan menyokong belajar selanjutnya (Slameto, 2003). Media pembelajaran adalah perantara sampainya pesan belajar dari sumber pesan kepada penerima pesan, sehingga terjadi interaksi belajar mengajar (Munir, 2008). Cecep (2011:7), menyatakan bahwa media adalah Alat-alat grafis, fotografis dan elektronis untuk menangkap, memproses dan menyusun kembali informasi visual atau verbal.

\section{METODE PENELITIAN}

Metode yang digunakan dalam penelitian ini yaitu metode eksperimen. dengan desain yang digunakan dalam penelitian ini adalah true experimental design dengan menggunakan bentuk posttest only control design. Setelah melaksanakan kegiatan pembelajaran pada masing-masing kelas yang sudah ditentukan metode belajarnya, maka selanjutnya dilakukan kuesioner atau angket yang diberikan kepada siswa sebagai responden pada masing-masing kelas, baik itu kelas kontrol maupun kelas eksperimen. Angket yang diberikan berupa pertanyaan dengan opsi jawaban yang telah tersedia, maka dapat dilihat pada skor akhir yang akan menunjukkan adanya peningkatan minat atau tidak setelah penggunaan media pembelajaran power point.

Variabel dalam penelitian ini terdiri dari variabel bebas dan variabel terikat. Variabel bebas (X) ialah media pembelajaran power point, sedangkan variabel terikat (Y) adalah minat belajar IPS.Populasi dari penelitian ini adalah seluruh siswa kelas VIII di SMP Negeri Sumber Harta tahun ajaran 2018/2019 yang berjumlah 128 orang.

Teknik pengambilan sampel yang digunakan dalam penelitian ini adalah Simple random Sampling.Pengambilan sampel dalam penelitian ini dilakukan dengan cara undian secara acak tanpa memandang strata yang ada di populasi itu. 
Sampel dalam populasi ini diambil $40 \%$ dari siswa kelas VIII di SMP Negeri Sumber Harta yang berjumlah 128 orang sebanyak 51 siswa.

Berdasarkan pengambilan sampel dengan teknik Simple random Sampling di atas, maka ditetapkan dua kelas sebagai sampel penelitian, yaitu kelas VIIIA sebanyak 25 siswa sebagai kelas eksperimen, dan kelas VIIIE 26 siswa sebagai kelas kontrol. Kelas eksperimen diberikan perlakuan dengan menggunakan media pembelajaran power point, dan kelas kontrol tidak diberikan perlakuan.

Teknik pengumpulan data yang digunakan ialah Teknik Angket yaitu menggunakan angket tertutup. Uji validasi menggunakan teknik korelasi product moment dengan taraf signifikan 5\% dan jumlah siswa 25 siswa dan $\mathrm{T}_{\text {tabel }}=1,71$. Setelah uji validitas, selanjutnya uji reabilitas. Pengujian reabilitas instrumen dalam penelitian ini dilakukan dengan menggunakan rumus Alpha Cronbach .

Teknik analisis data dalam penelitian menggunakan rumus persentase untuk menghitung nilai angka tentang minat belajar. Selanjutnya pengujian hipotesis menggunakan uji-t untuk mengetahui pengaruh penggunaan media pembelajaran power point terhadap minat belajar siswa.

\section{HASIL DAN PEMBAHASAN}

Penelitian dilakukan di SMP Negeri Sumber Harta yang terletak di Desa Sumber Harta, Kec. Sumber Harta, Kab. Musirawas, Provinsi Sumatera Selatan pada tahun pelajaran 2018/2019 dengan menggunakan dua kelas sampel penelitian yaitu kelas eksperimendan kelas kontrol. Pada kelas eksperimen yaitu kelas VIII A berjumlah 25 siswa dengan proses pembelajarannya menggunakan media pembelajaran Power Point sedangkan pada kelas kontrol yaitu kelas VIII.E berjumlah 26 siswa dengan proses pembelajarannya menggunakan metode konvensional. Pada pelaksanaan pembelajaran, peneliti bertindak sebagai pengajar.

Pada penelitian ini dilaksanakan pada tanggal 3 september 2018 sampai dengan 10 september 2018. Sebelum dilaksanakan pembelajaran diketahui bahwa siswa kurang berminat dalam pembelajaran IPS dan hasil belajar siswa masih tergolong rendah dan belum mencapai KKM. Setelah diketahui minat belajar siswa masih kurang maka peneliti melaksanakan pembelajaran dengan perlakuan yang berbeda pada kelas kontrol dan kelas eksperimen, kemudian dilakukan posttest untuk menentukan perbedaan minat belajar siswa antara kedua kelas. Minat belajar siswa diukur dengan memberikan post-test berupa angket minat belajar pada pembelajaran IPS yang dilakukan setelah siswa mengikuti proses belajar mengajar.

Berdasarkan hasil analisis menggunakan rumus persentase dapat dilihat bahwa skor angket kelas eksperimen kategori siswa yang sangat berminat sebanyak 23 siswa dengan persentase 92\%, siswa yang berminat sebanyak 2 siswa dengan persentase $8 \%$, siswa yang kurang berminat sebanyak 0 siswa dengan persentase $0 \%$, siswa yang tidak berminat sebanyak 0 siswa dengan 
persentase 0\%. Dari hasil perhitungan tersebut menunjukan bahwa ada pengaruh yang signifikan media pembelajaran power point terhadap minat belajar IPS siswa kelas VIII SMP Negeri Sumber Harta tahun pelajaran 2018/2019.

Tabel 1.

Analisis persentase kategori Minat Siswa

\begin{tabular}{lcc}
\hline \multicolumn{1}{c}{ Kategori Minat Siswa } & F & \% \\
\hline Sangat Berminat & 23 & $92 \%$ \\
\hline Berminat & 2 & $8 \%$ \\
\hline Kurang Berminat & 0 & $0 \%$ \\
\hline Tidak Berminat & 0 & $0 \%$ \\
\hline Total & 25 & $100 \%$ \\
\hline
\end{tabular}

Penelitian oleh Febriana (2018), yang meneliti pengaruh penggunaan media power point terhadap minat belajar sejarah siswa kelas X di SMA Negeri 1 Bumiayu menujukan bahwa ada pengaruh penggunaan media power point dalam pembelajaran sejarah terhadap minat belajar siswa. Hal ini ditunjukan dengan hasil tes angket yang menunjukan adanya peningkatan persentase siswa yang berminat terhadap pelajaran setelah menggunakan media pembelajaran power point.

Hipotesis dalam penelitian ini adalah ada pengaruh media power pointterhadap minat belajar IPS siswa kelas VIII di SMP Negeri Sumber Harta. Berdasarkan hasil analisis data menggunakan rumus uji-t diperoleh hasil perhitungan pada kelas eksperimen dan kelas kontrol bahwa minat belajar siswa kelas eksperimen lebih baik daripada kelas kontrol. Adapun hasil perhitungan uji$\mathrm{t}$ menunjukan $t_{\text {hitung }}(6,34)>t_{\text {tabel }}(1,68)$ maka $\mathrm{H}_{o}$ ditolak dan $\mathrm{H}_{a}$ diterima.Hal ini menyatakan bahwa minat belajar siswa kelas eksperimen tidak sama dengan kelas kontrol $\left(\mu^{1} \neq \mu^{2}\right)$. Dengan kata lain Ada Pengaruh Penggunaan Media Pembelajaran Power Point Terhadap Minat Belajar Siswa pada Mata Pelajaran IPS Kelas VIII di SMP Negeri Sumber Harta tahun pelajaran 2018/2019.

Media pembelajaran yang tepat akan menarik minat dan perhatian dari peserta didik. Levie \& Lentz (1982) dalam Arsyad (2014) mengemukakan tentang empat fungsi penggunaan media pembelajaran yaitu mencakup fungsi atensi, kognitif, afektif, dan psikomotor. Fungsi atensi diartikan jika penggunaan media untuk menarik dan mengarahkan perhatian peserta didik, fungsi kognitif berarti penggunaan media seperti adanya gambar atau simbol-simbol, gerak dan suara akan mempercepat pencapaian tujuan untuk memahami dan mengingat informasi atau pesan yang terkandung sehingga akan mempermudah proses berfikir penerimaan pesan. Penggunaan media informasi yang tepat dapat meningkatkan keinginan seseorang untuk mempelajari materi yang diberikan. Media memberikan pengaruh dalam mendorong (memotivasi) minat peserta didik (Taufik, 2007). 


\section{SIMPULAN}

Penggunaan media pembelajaran power point efektif digunakan dalam pembelajaran untuk meningkatkan minat belajar siswa pada mata pelajaran IPS kelas VIII di SMP Negeri Sumber Harta tahun pelajaran 2018/2019.

\section{DAFTAR PUSTAKA}

Arikunto, S. (2010). Prosedur Penelitian Suatu Pendekatan Praktek. Jakarta: Rineka Cipta.

Arsyad, A. (2014). Media pembelajaran. Jakarta: Rajawali Pers

Cecep, B.(2013). Media Pembelajaran. Bogor:Ghalia Indonesia.

Daryanto. (2013). Media Pembelajaran Peranannya Sangat Penting dalam Mencapai Tujuan Pembelajaran. Yogyakarta: Gava Media.

Djaali. (2008). Psikologi Pendidikan. Jakarta: PT Bumi Aksara.

Dona, F. (2017). Pengaruh Media Pembelajaran Power Point Terhadap Minat Belajar Siswa Pada Mata Pelajaran Sejarah Kelas X SMA Gajah Mada Bandar Lampung. Jurnal Pendidikan dan Penelitian Sejarah, 5(8)

Febriana, K. (2018). Pengaruh Media Pembelajaran Power Point Terhadap Minat Belajar Siswa Pada Mata Pelajaran Sejarah Kelas X SMA Gajah Mada Bandar Lampung.Indonesian Journal of History Educations, 6(1)

Munir. (2008). KurikulumBerbasis Teknologi Informasi Dan Komunikasi. Bandung: Alfabeta.

Slameto. (2003). Belajar dan faktor-faktor yang mempengaruhinya. Jakarta: Rineka Cipta.

Taufik, M. (2007). Prinsip-prinsip promosi kesehatan dalam bidang keperawatan untuk perawat dan mahasiswa keperawatan. Jakarta: Info Medika. 